\title{
Wpływ pola elektromagnetycznego na rezystancję skóry ludzkiej - pomiary in vivo
}

\section{In vivo measurement of the electromagnetic field effect on human tissue resistance}

\author{
Agata Pietrzak ${ }^{1}$ \\ ${ }^{1}$ Zakład Medycyny Nuklearnej
}

\section{Streszczenie}

Tkanka ludzka wykazuje czynne i bierne właściwości elektryczne. Czynną nazywamy zdolność do samoistnego wygenerowania potencjału czynnościowego, bierną jest przewodzenie ładunków elektrycznych.Ciałoludzkiejestnietylkowrażliwenaoddziaływaniezewnętrznegopolaelektromagnetycznego, ale także samo je generuje. Jedną z metod klinicznych,wykorzystujących odpowiedź elektryczną tkanek biologicznych na doprowadzone do nich zewnętrzne pole elektromagnetyczne jest spektroskopia bioimpedancyjna. Metody bioimpedancyjne znalazły szerokie zastosowanie, m.in. w dietetyce do oceny poziomu elektrolitów w organizmie. Celem przeprowadzonych badań było wykazanie wpływu zmian częstotliwości zewnętrznego sygnału elektrycznego na bioimpedancję tkanki ludzkiej.

Badania przeprowadzono w Zakładzie Bioniki i Bioimpedancji Uniwersytetu Medycznego im. K. Marcinkowskiego na dziesięcioosobowej grupie młodych, zdrowych studentów płci żeńskiej w wieku 19-24 lat. Do pomiaru użyto elektrod umieszczonych na szyi i palcu każdego uczestnika badania, do których doprowadzono przewody sygnałowe i pomiarowe $\mathrm{z}$ analizatora impedancji HIOKI $3522-50$ LCR. Analizowanym parametrem była wartość rezystancji skóry wskazanych segmentów ciała ludzkiego w zależności odzmian częstotliwości pola elektromagnetycznego w określonym zakresie $500 \mathrm{~Hz}-10 \mathrm{okHz}$.

Analiza wykazała, że istnieje odwrotnie proporcjonalna zależność między zmianą częstotliwości pola elektromagnetycznego a wartością bioimpedancji, co oznacza, że wzrost częstotliwości skutkuje spadkiem rezystancji tkanek. Badanie określiło również wpływ ukrwienia segmentu ciała ludzkiego oraz stopnia nawilżenia skóry na wzrost wartości bioimpedancji.

\footnotetext{
Abstract

Adres do korespondencji

mgr Agata Pietrzak

Młodszy Asystent Elektroradiologii

Zakład Medycyny Nuklearnej

Wielkopolskie Centrum Onkologii,ul. Garbary 15, 61-866 Poznań, Polska

Telefon: +48615088789

e-mail: agata.pietrzak@wco.pl;
}

The biological tissue has active and passive electric properties. The excitability as an active property means that the tissue generates the action potential (nervous tissue, muscles). The passive function is the ability to conduct electricity. The human body is susceptible to the external electromagnetic field and produces 
it itself. The physiological tension fluctuates from $3 \mathrm{mV}$ (nervous tissue) to over $5 \mathrm{mV}$ (muscles). One of the methods using the natural bioelectricity is the bioimpedance, which is very common in dietetics to evaluate the physiological fluids level.

The aim of this study is to demonstrate that fluctuating frequency of external electromagnetic field affects human tissue by resistance (bioimpedance) alteration.

The tests were performed in the Bionic and Bioimpedance Institute of the University of Medical Sciences in Poznań. The study group comprised 10 volunteers - healthy female students, age range 19-24 years. To measure the human tissue resistance, the investigator used the HIOKI 3522 - 50 LCR impedance analyser and two electrodes (neck, finger). The tested factor was the relation between the human tissue resistance and the frequency of electromagnetic field within the specified range of $500 \mathrm{~Hz}-100 \mathrm{kHz}$.

The human tissue boimpedance is inversely related to the fluctuation of the electromagnetic field frequency. Moreover, there is undisputed relation between the skin resistance and its blood supply or hydration.

Stowa kluczowe: : bioimpedancja, przewodnictwo elektryczne

Keywords: bioimpedance, electrical conduction

\section{Wstęp}

- Wtaściwości bioelektryczne tkanek

Tkanki ludzkie wykazują czynne i bierne właściwości elektryczne [1]. Czynne oznaczają zdolność do samoistnego wygenerowania impulsu elektrycznego, tj. potencjału czynnościowego (tkanka mięśniowa, nerwowa), bierne natomiast transport ladunku elektrycznego - prądu (tkanka łączna, tłuszczowa, a także cytoplazma).

O biernych właściwościach elektrycznych tkanki decyduje poziom elektrolitów w jej strukturze, czyli płynu, w którego skład wchodzą woda oraz jony potasu, sodu, wapnia i chloru. Właściwości elektryczne tkanek znalazły szerokie zastosowanie

w medycynie,np.w elektrokardiografii, elektromiografii, elektroencefalografii oraz bioelektrycznej analizie impedancyjnej, czyli pomiarze impedancji elektrycznej (bioimpedancji) $\mathbf{Z}$.

Bioimpedancję wyraża się następująco [1]:

\section{$\mathbf{Z}=\mathbf{U} / \mathbf{I}$}

gdzie, I jest natężeniem prądu przepływającym przez tkankę pod wpływem egzogennego napięcia $\mathbf{U}$, doprowadzonego do tego materiału biologicznego.

\section{- Wskazania kliniczne badania bioimpedancji}

Zastosowanie kliniczne metod bioimpedancyjnych jest obecnie coraz szersze. Na szczególną uwagę zasługuje tutaj BIA (bioelektryczna analiza impedancyjna), służąca ocenie ilości płynów wewnątrzi zewnątrzkomórkowych u chorych, np. z puchliną brzuszną, niedowładem, oparzeniem. Nie bez znaczenia pozostaje również zastosowanie pomiarów impedancyjnych narządów człowiekaw elektrochirurgii (elektrokoagulacja, skalpele termiczne), reoangiografii kończyn, kardiografii impedancyjnej. Aktualnie rozpowszechniona jestw dietetyce do pomiaru całkowitej zawartości wody i tłuszczu w organizmie celem planowania diety, np. dla osób cierpiących na cukrzycę, otyłość czy alergie pokarmowe. Największą efektywność badania uzyskujemyw zakresie częstotliwości 5 - $200 \mathrm{kHz}[1,2,3]$. Jest to metoda całkowicie bezbolesna i nieinwazyjna, wymagająca odpowiedniego sprzętu, przeszkolenia oraz umiejętności interpretowania wyników przez jej wykonawcę.

\section{- Cel pracy}

Celem pracy jest wykazanie, że istnieje wyraźny wpływ zmian częstotliwości pola elektromagnetycznego 
na bioimpedancję skóry ludzkiej na przykładzie tkanek szyi i palca oraz jednoznaczne określenie charakteru oraz przyczyn tej zależności.

\section{Material i metoda badań}

Badania przeprowadzono w Zakładzie Bioniki i Bioimpedancji Uniwersytetu Medycznego im. K. Marcinkowskiego w Poznaniu na kierunku Elektroradiologia podczas ćwiczeń studentów z przedmiotu: Zaawansowane metody elektrodiagnostyki i elektrofizjologii. Dziesięcioosobowa grupa badana składała sięz młodych, zdrowych studentów płci żeńskiej w wieku 19-24. Do wykonania pomiarów użyto analizatora impedancji HIOKI 3522 - 50 LCR w zakresie częstotliwości f pola elektrycznego od 50oHz do $100 \mathrm{kHz}$.

Mierzonym parametrem była składowa rezystancyjna $\mathbf{R}$ bioimpedancji $\mathbf{Z}$ skóry, która odzwierciedla mechanizm przewodnictwa elektrycznego tkanki.

Rycina 3 ilustruje punkty pomiarowe z nałożonymi elektrodami (Ag/AgCl), do których podłączono przewody sygnałowe i pomiarowe z miernika HIOKI.

- System mono - i bipolarny $w$ pomiarach bioimpedancyjnych

W zależności od wskazań klinicznych stosowano dwa systemy pomiarowe: mono - i bipolarne [4]. Celem systemu monopolarnego jest uzyskanie jak największej gęstości ładunków elektrycznych pod elektrodą czynną o większej powierzchni, gdy druga - neutralna, stanowi pomiarowy punkt odniesienia. W systemie bipolarnym natomiast uzyskuje się równomierny rozkład gęstości prądu pomiędzy obiema elektrodami o tej samej powierzchni. Przepływ prądu elektrycznego między elektrodami dla systemu monopolarnego i bipolarnego jest uwidoczniony odpowiednio na rycinach 1 i 2 [1, 4].

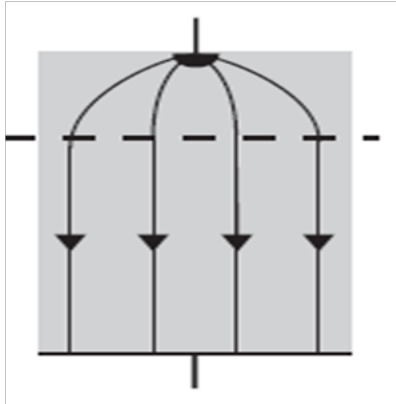

Rycina 1. Układ monopolarny elektrod

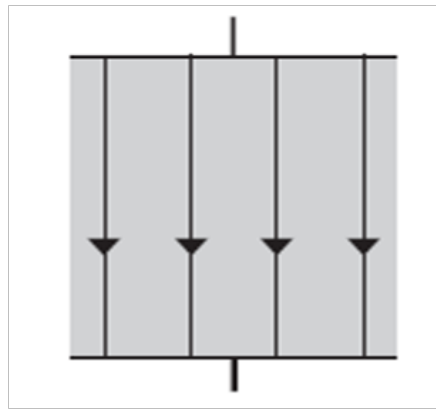

Rycina 2. Układ bipolarny elektrod

Do badania wykorzystano metodę dwuelektrodową w systemie bipolarnym. Na skórze badanej osoby umieszczono cztery elektrody: dwie na karku i dwie na palcu.Zmierzono rezystancję skóry między elektrodami doprowadzając do nich z miernika sygnał zmiennoprądowy o kilku wybranych częstotliwościach (ryc.3).
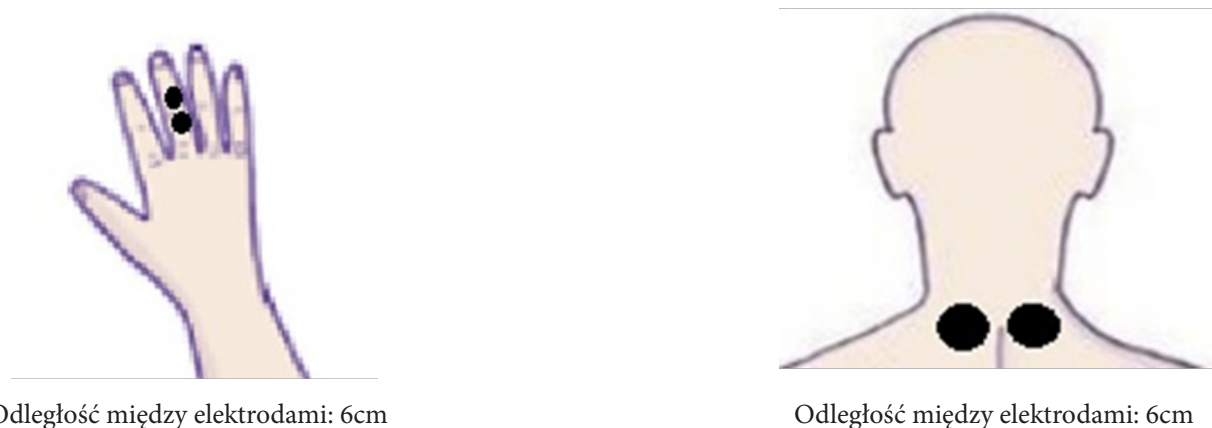

Rycina 3.Schemat rozmieszczenia elektrod (w oparciu o www.bodyclock.pl) 


\section{Wyniki}

Tabela 1. Wyniki badań rezystancji szyi i palca

\begin{tabular}{|c|c|c|c|c|c|}
\hline Badani & 500 & 5000 & 50000 & 100000 & Częstotliwość $[\mathrm{Hz}]$ \\
\hline Szyja1 & 5200 & 511 & 67 & 54 & Rezystancja $[\Omega]$ \\
\hline Palec 1 & 5500 & 987 & 299 & 180 & \\
\hline Szyja2 & 3300 & 287 & 62 & 52 & \\
\hline Palec2 & 4400 & 417 & 123 & 112 \\
\hline Szyja3 & 3300 & 460 & 71 & 53 \\
\hline Palec3 & 3900 & 582 & 101 & 83 \\
\hline Szyja4 & 4000 & 369 & 55 & 45 \\
\hline Palec4 & 5000 & 629 & 111 & 90 \\
\hline Szyja5 & 5100 & 561 & 76 & 58 \\
\hline Palec5 & 5500 & 684 & 120 & 101 \\
\hline Szyja6 & 2750 & 345 & 62 & 51 \\
\hline Palec6 & 3490 & 829 & 163 & 138 \\
\hline Szyja7 & 5100 & 426 & 65 & 52 \\
\hline Palec7 & 5480 & 949 & 131 & 98 \\
\hline Szyja8 & 2700 & 345 & 62 & 51 \\
\hline Palec8 & 3500 & 829 & 163 & 138 \\
\hline Szyja9 & 5180 & 550 & 65 & 49 \\
\hline Palec9 & 5350 & 820 & 148 & 126 \\
\hline Szyja10 & 5200 & 550 & 65 & 49 \\
\hline Palec10 & 5300 & 829 & 148 & 126 & \\
\hline
\end{tabular}

1, 2, 3,... - numery studentów biorących udział w badaniu, Odległość między elektrodami: szyja $6 \mathrm{~cm}$ palec: $6 \mathrm{~cm}$

Na rycinach 4 i 5 przedstawiono odpowiednio częstotliwościowe zależności rezystancji szyi i palca w skali logarytmicznej.

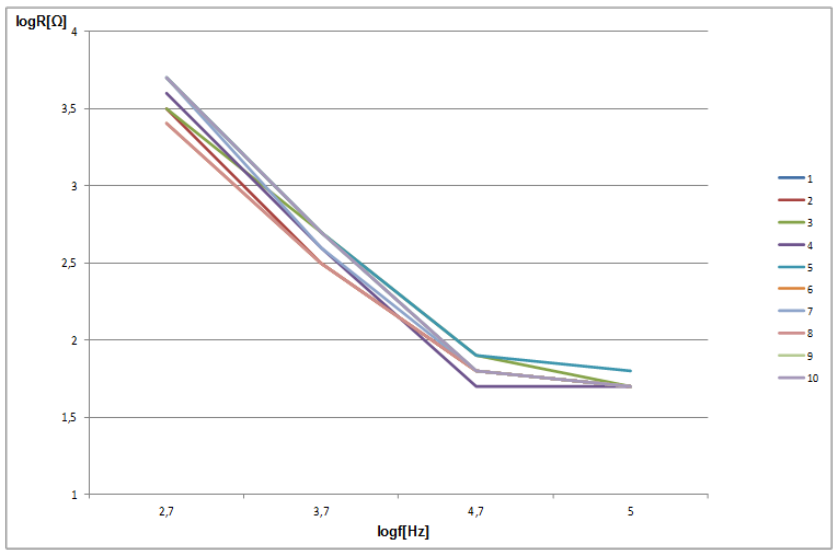

Rycina 4. Wpływ częstotliwości prądu na rezystancję tkanek szyi

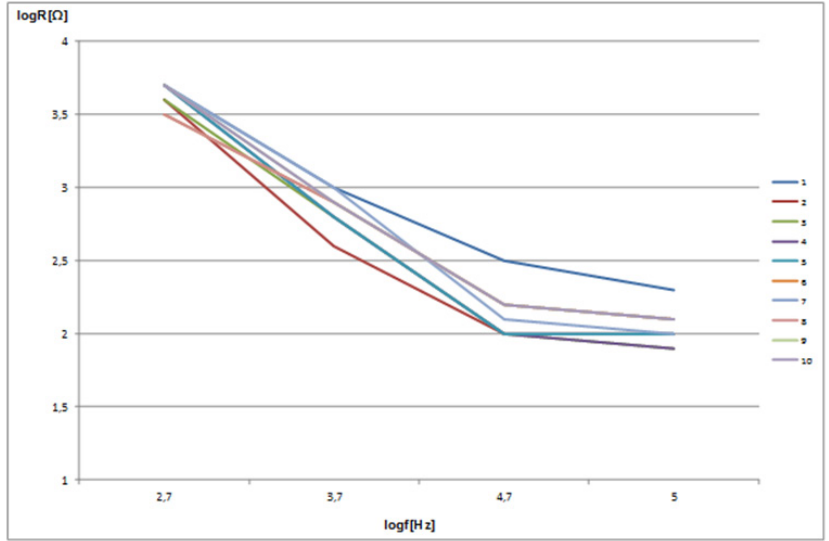

Rycina 5. Wpływ częstotliwości prądu na rezystancję tkanek palca 
Na rycinie 6 uwidoczniono dla porównania średnie wartości rezystancji szyi i palca otrzymane na podstawie Tabeli 1.

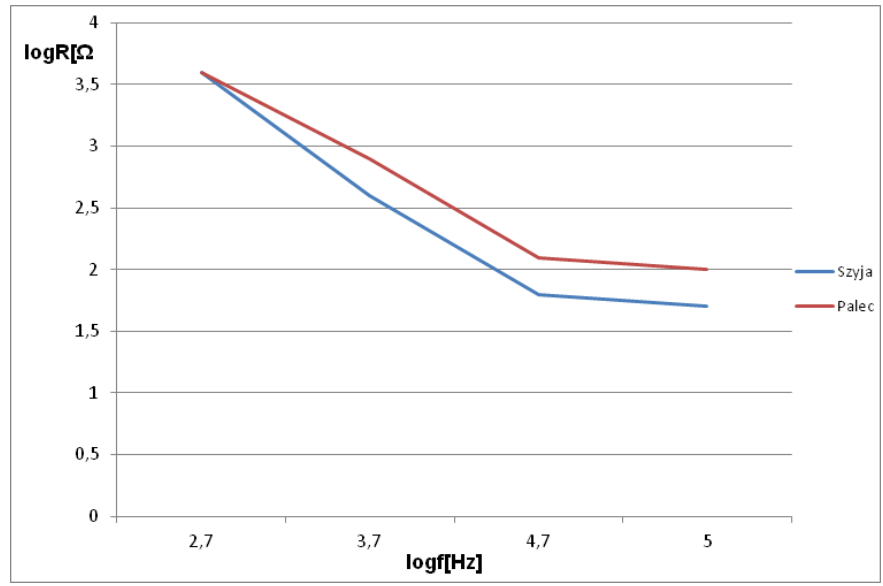

Rycina 6. Analiza porównawcza wpływu częstotliwości prądu na rezystancję tkanek szyi i palca

\section{Dyskusja}

Ryciny 4-6 ilustrują krzywe dyspersyjne dla szyi i palca, opisujące mechanizm przewodzenia prądu elektrycznego w tych tkankach, czyli zależność wpływu zmian częstotliwości pola elektromagnetycznego na bioimpedancję tkanki ludzkiej. Wyższe wartości oporu elektrycznego dla palca są wynikiem niejednakowej zawartości elektrolitów w badanych segmentach, ściśle związanej z różnicami w budowie anatomicznej i własnościach fizjologicznych omawianych obszarów.

Przez obszar szyi przebiegają parzyste tętnice o dużym polu przekroju: tętnice szyjne wspólne, zaopatrujące mózg w bogatą w jony krew. W budowie anatomicznej kończyny górnej nie wyróżnia się dużych naczyń krwionośnych, zapewniających podobnie intensywny napływ elektrolitów i stale wysokie stężenie jonów, co warunkuje dużą przewodność elektryczną. Fizjologia tego obszaru natomiast wskazuje dużą zależność oporu elektrycznego od motoryki kończyny. Wykonywanie czynności manualnych wymusza zwiększony przepływ krwi, czyli ruch jonów, co skutkuje spadkiem bioimpedancji. W przypadku szyi obserwuje się ciągłyi intensywny napływ krwi do mózgu, toteż przewodnictwo elektryczne w tym segmencie ciała ludzkiego jest większe niż w palcu [5,6].

Z punktu widzenia krążenia oraz stężenia elektrolitów, nie bez znaczenia pozostaje odległość od osi centralnej ciała. W obrębie osi długiej, w której leży szyja, znajduje się serce i ważne dla życia narządy, czyli ośrodki silnie zaopatrywane w krew i wykazujące w związku z tym zmniejszoną rezystancję w stosunku do kończyn.

Istotną rolę odgrywa również unerwienie wybranych segmentów (tkanka nerwowa jest najsilniej uwodnioną tkanką organizmu) oraz stopień nawilżenia skóry. Bogato unerwiona szyja wykazuje mniejszą rezystancję elektryczną niż palce, gdyż przewodzi prąd o większym natężeniu. O wilgotności skóry decyduje liczba i aktywność wydzielnicza gruczołów potowych, szczególnie ekrynowych, których produkt to elektrolit, składający się niemal wyłącznie z wody. Im wyższa aktywność gruczołowa, tym wyższe stężenie elektrolitów, większe przewodnictwo elektryczne tkanki i mniejsza bioimpedancja $[5,6,7,8]$.

\section{Wnioski}

1. Wzrost częstotliwości sygnału elektrycznego doprowadzonego do szyi i palca powoduje spadek bioimpedancji tych tkanek, czyli wzrost przewodnictwa elektrycznego.

2. Tkanki w obszarze szyi wykazują mniejszą bioimpedancję niż kończyna górna dla tej samej częstotliwości pola elektromagnetycznego, co wynikaz budowy anatomicznej i fizjologii badanych struktur. 
3. Do najważniejszych czynników decydujących o wartości rezystancji elektrycznej badanych tkanek należą: stopień nawilżenia skóry oraz ukrwienie tkanek, co decyduje o zawartości elektrolitów, a w konsekwencji - o liczbie nośników ładunku zdolnych do przewodzenia prądu elektrycznego.

\section{Konflikt interesu / Conflict of interest}

Nie występuje / None

\section{Etyka / Ethics}

Treści przedstawione w artykule są zgodne z zasadami Deklaracji Helsińskiej, dyrektywami EU oraz ujednoliconymi wymaganiami dla czasopism biomedycznych.

\section{Piśmiennictwo / References}

[1] Pander T., Czabański R., Reografia impedancyjna, skrypt Politechniki Śląskiej w Gliwicach, Gliwice 2010.

[2] Pawlicki G., Pałko T., Golnik N., Gwiazdowska B., Królicki L., Biocybernetyka i Inżynieria Biomedyczna pod red. Macieja Nałęcza, Akademicka Oficyna Wydawnicza EXIT, Warszawa 2002, Fizyka Medyczna tom 9, rozdział 8,ISBN83-87674-37-0.

[3] Lewitt A., Mądro E., Krupienicz A., Podstawy teoretyczne i zastosowanie analizy impedancji bioeletrycznej BIA,Endokrynologia, Otyłość i Zaburzenia Przemiany Materii 2007, tom 3, nr 4, ISSN $1734-3321$.

[4] Grimnes S., Martinsen Ø.G.: Bioimpedance and Bioelectricity Basics. Academic Press, 2008.

[5] Traczyk W., Fizjologia człowieka w zarysie, PZWL, Warszawa 1989, rozdział 1, 2 i 5, ISBN 83-200-1370-4.

[6] Sokołowska - Pituchowa J., Anatomia człowieka. Podręcznik dla studentów medycyny, Wydanie VIII, PZWL, Warszawa 2008, ISBN 978-83-200 -3917-7.

[7] Biedermann T., Human eccrine sweat gland cells can reconstitute a stratified epidermis, rozprawa doktorska, Archiwum Uniwersytetu w Zurychu, Zurych 2011.

[8] Freinkel RK, Woodley DT. The biology of the skin. Hurley HJ. Rozdział 3: The eccrine sweat glands: structure and function. Parthenon Publishing 2001.

\section{Podpisy rycin i tabel}

[Ryc.1.] Układ monopolarny: system dwuelektrodowy (źródło: Zakład Bioniki i Bioimpedancji, Wydział Nauk o Zdrowiu, Uniwersytet Medyczny im. K. Marcinkowskiego w Poznaniu)

[Ryc.2.] Układ bipolarny: system dwuelektrodowy (źródło: Zakład Bioniki i Bioimpedancji, Wydział Nauk o Zdrowiu, Uniwersytet Medyczny im. K. Marcinkowskiego w Poznaniu)

[Ryc.3.] Schemat rozmieszczenia elektrod (źródło: rycina własna w oparciu o www.bodyclock.pl)

[Ryc.4.] Wpływ częstotliwości prądu na rezystancję tkanek szyi (źródło: rycina własna autora)

[Ryc.5.] Wpływ częstotliwości prądu na rezystancję tkanek palca (źródło: rycina własna autora)

[Ryc.6.] Analiza porównawcza wpływu częstotliwości prądu na rezystancję tkanek szyi i palca (źródło: rycina własna autora)

[Tabela.1.]Wyniki badań rezystancji szyi i palca 